\title{
TSC1 Gene Mutation
}

National Cancer Institute

\section{Source}

National Cancer Institute. TSC1 Gene Mutation. NCI Thesaurus. Code C118398.

A change in the nucleotide sequence of the TSC1 gene. 